Obere Extremität 2018 · 13:106-111 https://doi.org/10.1007/s11678-018-0459-z Received: 25 February 2018

Accepted: 17 April 2018

Published online: 15 May 2018

(c) The Author(s) 2018

\title{
CrossMark
}

Fractures of the greater tuberosity (GT) often occur with more complex proximal humerus fractures and are less frequently observed as an isolated pathology. Only $14-20 \%$ of proximal humerus fractures are isolated lesions of the GT $[4,15,23]$. Up to $30 \%$ of these fractures are associated with anterior glenohumeral dislocations [25].

According to Neer, a displacement of the fragment of $>10 \mathrm{~mm}$ and $45^{\circ}$ (later modified to $>5 \mathrm{~mm}$ and $30^{\circ}$ ) is believed to be an indication for operative treatment [20]. However, whether all other fractures can be managed successfully by nonoperative treatment is unclear. Currently, there is a lack of evidence in the literature to support either conservative or operative treatment strategies in GT fractures. Whether the fracture type and the etiology of the fracture impact the decision-making and the final outcome also remains unclear.

There are only a few reports on conservative treatment of isolated GT fractures. Platzer et al. compared the functional results of 52 patients who underwent open reduction and internal fixation (ORIF) of a GT fracture with nine patients who were treated conservatively for similar fractures. All patients had a displaced fracture $(>5 \mathrm{~mm})$ [23]. After a mean followup of 5.5 years, functional results were significantly better after operative treatment than they were after conservative treatment. The same authors reported on 135 conservatively treated patients with an isolated GT fracture and found worse

Benedikt Schliemann' • Lukas F. Heilmann' • Michael J. Raschke' • Helmut Lill ${ }^{2}$ J. Christoph Katthagen ${ }^{1} \cdot$ Alexander Ellwein $^{2}$

' Department of Trauma, Hand and Reconstructive Surgery, University Hospital Münster, Münster, Germany

${ }^{2}$ Traumatology and Reconstructive Surgery, Diakovere Friederikenstift GmbH, Hannover, Germany

\section{Isolated fractures of the greater tuberosity: When are they treated conservatively?}

\section{A baseline study}

results in fractures with $>3 \mathrm{~mm}$ displacement [22]. Similarly, other authors reported good to excellent results in their patients who had conservative treatment for minimally displaced fractures $[12,17$, 24].

The present baseline study aimed to analyze under what circumstances isolated fractures of the GT are managed conservatively. In addition to the indication for conservative treatment, the rate of secondary interventions for failed conservative treatment is evaluated.

\section{Patients and methods}

A retrospective data evaluation of isolated GT fractures was performed from the clinical database of two german levelI trauma centers from January 2010 to June 2017. A total of 114 patients with a GT fracture were initially treated conservatively. The mean age of the patients at the time of the injury was 55 years (range, 18-94 years). The mechanism of the injury was a direct fall on the affected shoulder in 61 cases, a traffic accident in nine cases, and an anterior shoulder dislocation in 44 cases. All patients had conventional radiographs of the shoulder in the anteroposterior, axillary, and Y-view. After an isolated fracture of the GT was identified, the degree of displacement was assessed and classified as: (1) no displacement, (2) mild displacement (1-3 mm), or (3) severe displacement $(>3 \mathrm{~mm})$. Impression fractures (usually related to glenohumeral dislocations) comprised a fourth group. The fractures were further subdivided into simple fractures with only a single fragment and comminuted fractures with two or more fragments.

The indication for conservative treatment was analyzed according to the patients' records. A follow-up period of at least 6 months was mandatory in order to evaluate secondary surgical interventions. Interventions were further subdivided into fracture-related procedures and procedures required for associated lesions, such as capsulolabral tears in patients who sustained a shoulder dislocation or posttraumatic stiffness.

\section{Results}

A total of 114 patients were identified. In six patients with severe displacement, operative treatment was recommended, but severe comorbidities (i.e. cardiovascular conditions) prevented surgical interventions. In addition, two patients refused to undergo surgery despite severe concomitant soft tissue lesions, and one patient did not return to the hospital after an magnetic resonance imaging (MRI) was indicated. These nine patients were excluded from the study. Of the remaining 105 fractures, 72 (68.6\%) were not displaced (• Fig. 1), a mild displacement of $1-3 \mathrm{~mm}$ was found in 27 cases $(25.7 \%)$, severe displacement $(>3 \mathrm{~mm}$ ) was found in two cases $(1.9 \%)$, and the remaining four fractures $(3.8 \%)$ were classified as impression fractures (depression type 

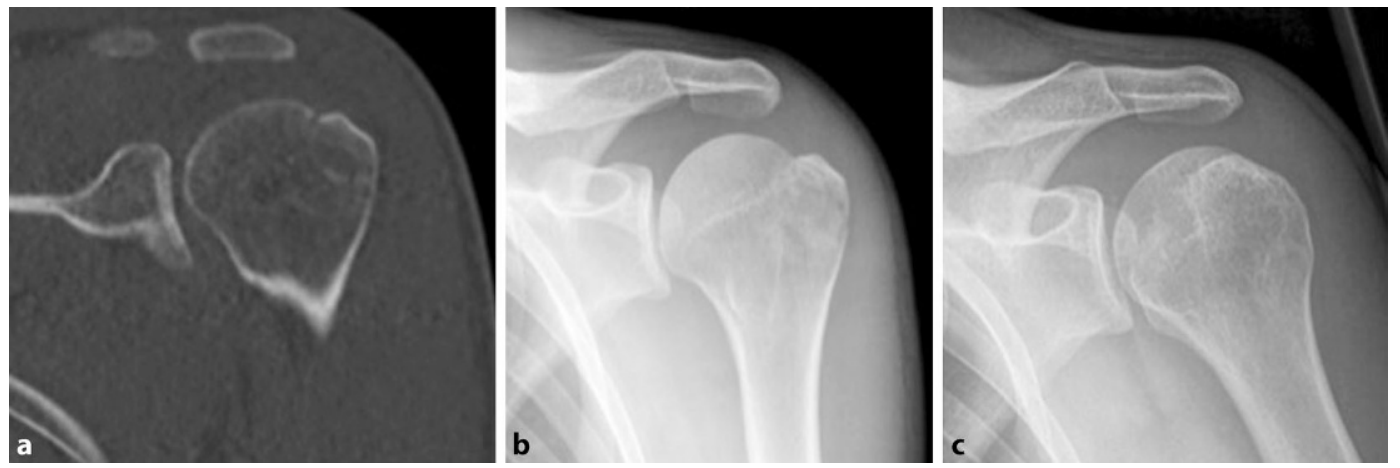

Fig. $1<$ Conservatively treated fracture of the greater tuberosity: initial radiograph (a), follow-up after 3 weeks to exclude secondary displacement (b), and anatomic consolidation 3 months after the injury (c)

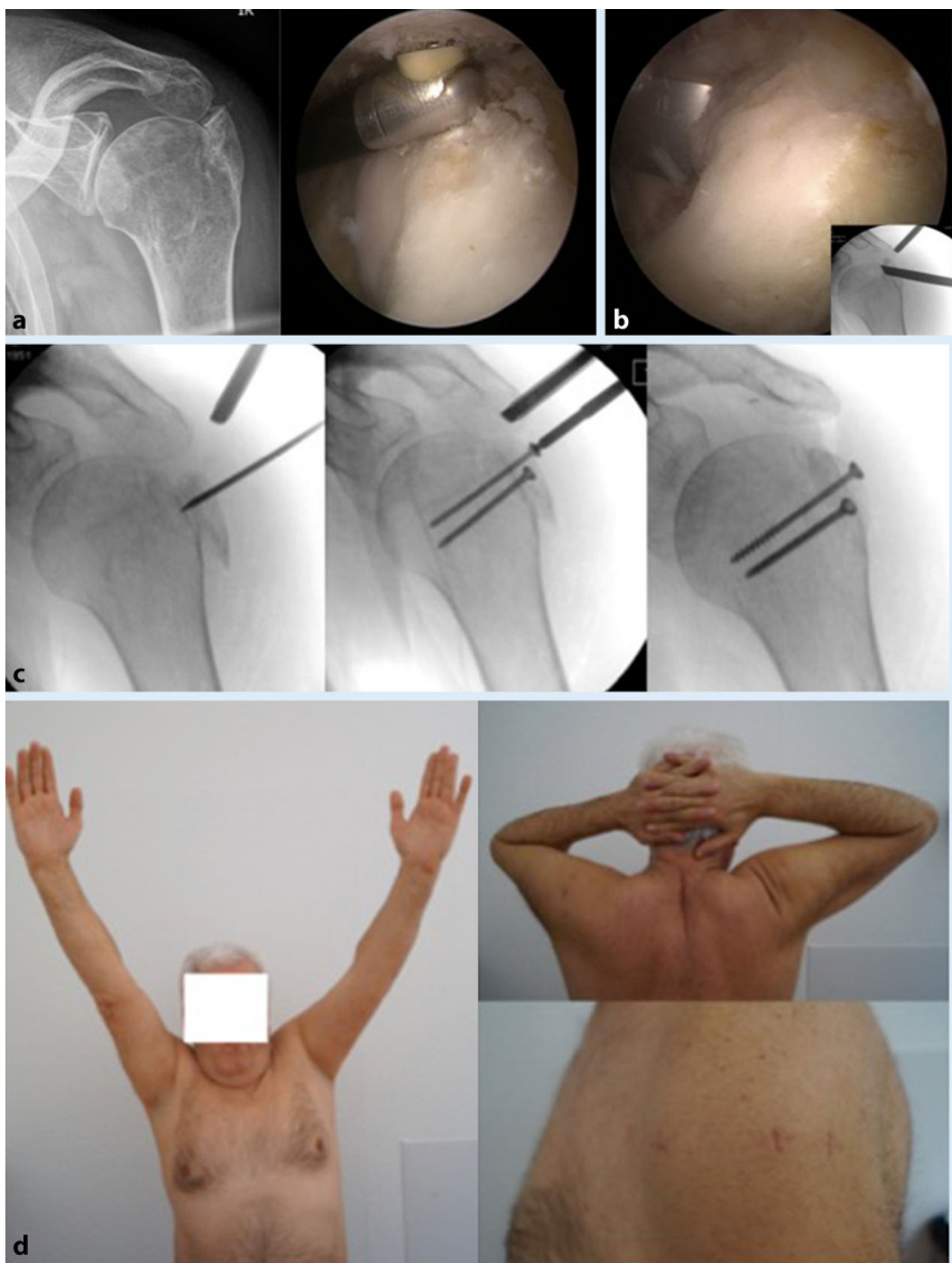

Fig. $2<$ a Posterosuperior malunion of a solid greater tuberosity fracture. Preoperative anteroposterior radiograph (left) and intraoperative finding (right). b Osteotomy of the fragment (left) with corresponding fluoroscopy (inset) and external view (right). c Under arthroscopic and fluoroscopic guidance, the fragment is reduced and fixed with two $3.5-\mathrm{mm}$ screws. d Functional outcome four months postoperatively

fracture). The decision to treat the two cases with more severe displacement conservatively was made based on an initial displacement of $4 \mathrm{~mm}$. $51 \%$ of the fractures were simple and $49 \%$ had multiple fragments. Comminuted fractures were more likely to occur with shoulder dislocations (57\%). In the acute situation, all fractures were treated conservatively with the affected arm immobilized in an abduction brace to release tension from the rotator cuff on the fracture site. Passive motion was allowed with range of motion (ROM) limited to $90^{\circ}$ of flexion and abduction, free external rotation, and no internal rotation for the first 3 weeks.
Patients were reexamined clinically and radiographically to identify secondary displacements. If the patient had further complaints, MRI was performed to analyze the integrity of the rotator cuff and the capsuloligamentous complex.

Of the remaining 105 patients, 17 underwent secondary surgical inter- 
Obere Extremität 2018 · 13:106-111 https://doi.org/10.1007/s11678-018-0459-z

(c) The Author(s) 2018

\section{B. Schliemann · L. F. Heilmann · M. J. Raschke · H. Lill · J. C. Katthagen · A. Ellwein}

\section{Isolated fractures of the greater tuberosity: When are they treated conservatively? A baseline study}

\section{Abstract}

Background. This study analyzed the indications for conservative management of isolated greater tuberosity (GT) fractures. The rate of secondary interventions for failed conservative treatment was also assessed. Methods. A retrospective data evaluation of isolated GT fractures was performed from the clinical database of two level-I trauma centers from January 2010 to June 2017. Conservatively treated GT fractures were identified and subdivided according to etiology, morphology, and amount of initial displacement. Secondary surgical interventions were recorded and subcategorized into fracture-associated interventions and interventions for associated soft tissue lesions.
Results. We identified 114 fractures. Nine cases were excluded because patients refused surgery or their comorbidities ruled it out. Only two of the remaining 105 patients had an initial displacement $>3 \mathrm{~mm}$. All other GT fractures $(n=103,98 \%)$ were not displaced or only slightly displaced $(0-3 \mathrm{~mm})$. The fracture was associated with an anterior shoulder dislocation in 39 cases $(37 \%)$; 17 patients (16.2\%) underwent surgery after primary conservative treatment. Four of these 17 patients presented with a secondary displacement of the GT fragment. In all other cases (76.5\%), an associated soft tissue lesion necessitated revision surgery. Young age, anterior shoulder dislocation, and concomitant injuries were risk factors for revision surgery after primary conservative treatment.

Conclusion. Secondary interventions are required more frequently after shoulder dislocation. Surgery is most likely required for associated soft tissue lesions rather than for secondary displacements. Thus, detailed physical examination and magnetic resonance imaging should be used to screen for concomitant soft tissue injuries accompanying GT fractures to prevent revision surgeries.

Keywords

Greater tuberosity fracture $\cdot$ Shoulder dislocation - Proximal humeral fractures . Concomitant lesions · Surgery

\section{Isolierte Tuberculum-majus-Frakturen: Wann werden sie konservativ behandelt? Eine Statuserhebung}

\section{Zusammenfassung}

Hintergrund. Ziel der vorliegenden Arbeit war es, die Indikationen für eine konservative Behandlung bei isolierten Frakturen des Tuberculum majus (TM) zu ermitteln. Darüber hinaus wurde die Rate sekundärer chirurgischer Interventionen bei Versagen der konservativen Therapie erfasst.

Methoden. Es erfolgte eine retrospektive Auswertung der Datenbanken zweier LevelI-Traumazentren, in denen isolierte TMFrakturen von Januar 2010 bis Juni 2017 erfasst wurden. Die konservativ behandelten Frakturen wurden nach ihrer Ätiologie sowie der Morphologie und Dislokation des Fragments ausgewertet und unterschieden. Sekundäre chirurgische Interventionen wurden erfasst und ebenfalls weiter unterschieden in frakturassoziierte Maßnahmen und in Interventionen, die aufgrund von mit Weichteilverletzungen erforderlich wurden.
Ergebnisse. Es wurden 114 TM-Frakturen identifiziert. Neun Fälle wurden aus der Studie ausgeschlossen, weil die Patienten die empfohlene operative Therapie ablehnten oder diese aufgrund von Komorbiditäten nicht möglich war. Bei nur 2 der verbliebenen 105 Patienten war die Fraktur $>3 \mathrm{~mm}$ disloziert, alle anderen TM-Frakturen ( $n=103,98 \%)$ waren initial nicht oder nur leicht disloziert (0-3 mm). In 39 Fällen (37\%) war die Fraktur mit einer anterioren Schulterluxation assoziiert. Bei 17 Patienten (16,2\%) erfolgte nach initialer konservativer Therapie eine sekundäre chirurgische Intervention. Bei 4 dieser 17 Patienten war die Revision wegen einer sekundären Dislokation des TM-Fragments notwendig. In allen anderen Fällen (76,5\%) machte eine assoziierte Weichteilverletzung die sekundäre Operation erforderlich. Junges Patientenalter, eine anteriore Schulterluxation und begleitende
Weichteilverletzungen stellten Risikofaktoren dar, welche die Wahrscheinlichkeit für eine sekundäre chirurgische Intervention nach primär konservativer Therapie erhöhten. Schlussfolgerung. Sekundäre chirurgische Interventionen sind häufiger nach anteriorer Schulterluxation und mit größerer Wahrscheinlichkeit bei begleitenden Weichteilverletzungen als bei sekundären Dislokationen notwendig. Daher sollte durch eine detaillierte körperliche Untersuchung und ggf. durch eine MRT der Fokus auf die Suche nach begleitenden Weichteilverletzungen bei TM-Frakturen gelegt werden, um Revisionsoperationen vorzubeugen.

\section{Schlüsselwörter}

Tuberculum-majus-Fraktur · Schulterluxation Proximale Humerusfrakturen . Begleitverletzungen - Operation ventions (16.2\%). In only four cases, including the two patients with initial displacement of the GT fragment $>3 \mathrm{~mm}$, a surgical revision was required owing to a secondary displacement of the fracture with subsequent impingement and limited ROM (• Fig. 2). In all other cases $(n=13)$, an associated soft tissue lesion led to a secondary surgical intervention. The different pro- cedures are listed in - Table 1. Given that three patients refused to undergo surgery despite an indication because of secondary displacement and subsequent limited ROM, the revision rate would have increased to $19 \%$.

Patients for whom a shoulder dislocation was the cause of the GT fracture were more likely to undergo secondary surgical intervention (20.5\% vs. $13.6 \%)$.
However, this difference was not statistically significant $(p=0.415)$.

The fracture morphology (single fragment vs. comminuted fractures) had no significant impact on the risk for secondary interventions.

By contrast, the amount of the initial displacement of the fragment is an indicator of secondary displacement and surgical revisions; all patients with primary 


\begin{tabular}{|c|c|c|c|c|c|c|}
\hline $\begin{array}{l}\text { Patient } \\
\text { age }\end{array}$ & Gender & $\begin{array}{l}\text { Displacement } \\
\text { diameter }\end{array}$ & $\begin{array}{l}\text { Trauma } \\
\text { mechanism }\end{array}$ & $\begin{array}{l}\text { Reason for secondary } \\
\text { surgery }\end{array}$ & Surgical intervention & $\begin{array}{l}\text { Time } \\
\text { point of } \\
\text { revision } \\
\text { surgery }\end{array}$ \\
\hline 77 & Female & $4 \mathrm{~mm}$ (cranial) & $\begin{array}{l}\text { Traumatic } \\
\text { shoulder dis- } \\
\text { location }\end{array}$ & Secondary displacement & ORIF PHILOS plate & 1 \\
\hline 80 & Female & $4 \mathrm{~mm}$ (cranial) & Fall & Secondary displacement & ORIF PHILOS plate & 2.5 \\
\hline 28 & Male & No displacement & Traffic accident & Secondary displacement & Twinfix anchor & 4.5 \\
\hline 46 & Female & No displacement & $\begin{array}{l}\text { Traumatic } \\
\text { shoulder dis- } \\
\text { location }\end{array}$ & $\begin{array}{l}\text { Secondary displace- } \\
\text { ment + LHBT tendinitis }\end{array}$ & $\begin{array}{l}\text { A. subacromial decompression + LHBT } \\
\text { tenodesis }\end{array}$ & 21 \\
\hline 64 & Male & No displacement & $\begin{array}{l}\text { Traumatic } \\
\text { shoulder dis- } \\
\text { location }\end{array}$ & LHBT tendinitis + SSP rupture & LHBT tenodesis + SSR & 13.5 \\
\hline 44 & Female & $3 \mathrm{~mm}$ (lateral) & Fall & $\begin{array}{l}\text { Malposition of healed frac- } \\
\text { ture + LHBT tendinitis + SSP } \\
\text { rupture }\end{array}$ & $\begin{array}{l}\text { LHBT tenodesis, tuberculoplasty, SST } \\
\text { repair }\end{array}$ & 84 \\
\hline 21 & Male & No displacement & $\begin{array}{l}\text { Traumatic } \\
\text { shoulder dis- } \\
\text { location }\end{array}$ & Bankart lesion & A. labral repair and capsular shift & 54 \\
\hline 25 & Male & $1 \mathrm{~mm}$ (cranial) & $\begin{array}{l}\text { Traumatic } \\
\text { shoulder dis- } \\
\text { location }\end{array}$ & Bankart lesion + PTSS & $\begin{array}{l}\text { A. arthrolysis, labral repair and capsular } \\
\text { shift }\end{array}$ & 20 \\
\hline 43 & Male & No displacement & $\begin{array}{l}\text { Traumatic } \\
\text { shoulder dis- } \\
\text { location }\end{array}$ & PTSS & A. arthrolysis & 16 \\
\hline 55 & Male & No displacement & $\begin{array}{l}\text { Traumatic } \\
\text { shoulder dis- } \\
\text { location }\end{array}$ & PTSS & $\begin{array}{l}\text { A. arthrolysis + LHBT tenode- } \\
\text { sis + acromioplasty }\end{array}$ & 24 \\
\hline 56 & Female & No displacement & Fall & PTSS + LHBT tendinitis & A. arthrolysis + LHBT tenodesis & 25 \\
\hline 57 & Female & No displacement & Traffic accident & PTSS + Impingement & A. arthrolysis + acromioplasty & 19 \\
\hline 45 & Male & No displacement & Fall & SST, SLAP, LHBT rupture & LHBT tenodesis + SSR & 25 \\
\hline 35 & Male & No displacement & Fall & SST & SSR + LHBT tenodesis & 28 \\
\hline 43 & Female & No displacement & Fall & SST & SSR & 24 \\
\hline 62 & Female & No displacement & Fall & Impingement & Subacromial decompression & 8 \\
\hline 29 & Male & $3 \mathrm{~mm}$ (cranial) & $\begin{array}{l}\text { Traumatic } \\
\text { shoulder dis- } \\
\text { location }\end{array}$ & Axillary nerve injury & $\begin{array}{l}\text { Neurolysis + decompression brachial } \\
\text { plexus }\end{array}$ & 30 \\
\hline
\end{tabular}

displacement of the GT fragment who were treated conservatively and needed revision surgery because of a secondary displacement of the GT fragment had a significant primary displacement of $\geq 3 \mathrm{~mm}$.

Moreover, younger patients tend to require secondary interventions more frequently than older patients. The mean age of the patients who underwent surgical intervention was 46 years (25-62 years), whereas the mean age of the cohort without secondary in- tervention was 56 years (18-94 years). However, this difference was not statistically significant $(p=0.148)$.

\section{Discussion}

The present database analysis revealed three major findings: First, the majority of conservatively treated isolated GT fractures (68.6\%) are nondisplaced, generally justifying conservative treatment. Second, the rate of secondary interventions was $16.2 \%$. Finally, most of the secondary surgical interventions were not related to the secondary displacement of the GT fracture but to concomitant lesions of the rotator cuff and the capsuloligamentous tissue.

According to the criteria originally defined by Neer, a displacement of $>10 \mathrm{~mm}$ and $45^{\circ}$ is an indication for surgery, and all other fractures can be successfully managed with a conservative approach [20]. Later, these criteria were modified to $5 \mathrm{~mm}$ and $30^{\circ}$ of displacement. However, it is known that as little as $2-5 \mathrm{~mm}$ 
of displacement can cause impingement and requires increased forces for abduction [7-9]. In particular, fragment displacement in the posterosuperior direction is associated with impaired function and worse results $[2,27]$. Therefore, operative treatment is recommended more aggressively, and numerous articles exist about different techniques and results [1, $3,5,6,13,17,23,26]$.

By contrast, there are only a few reports on conservative treatment of isolated GT fractures. Platzer et al. reported on the functional results of 135 patients treated conservatively for isolated GT fractures with less than $6 \mathrm{~mm}$ displacement [22]. They found good to excellent results in $97 \%$ of the cases. This is in accordance with results from other studies of conservative treatment $[12,17,20,23$, 24]. If the displacement is less than $5 \mathrm{~mm}$, satisfying results can be expected. In addition, the present study shows that patients with a nondisplaced or only slightly displaced fracture $(0-3 \mathrm{~mm})$ that did not arise from a shoulder dislocation have a low risk for secondary surgical interventions. Furthermore, fractures with an initial displacement of $3 \mathrm{~mm}$ or less are unlikely to have further displacement over time (only $2 \%$ in the present study). Patients who required secondary surgery after initial displacement had a primary fracture displacement of $>3 \mathrm{~mm}$.

Unfortunately, defining the degree of displacement has also been a matter of debate. When displacement is measured with only plain radiographs, errors of up to $13 \mathrm{~mm}$ have been described [21]. A computed tomography (CT) scan may help to minimize these errors. On the other hand, Janssen et al. observed that the imaging modality did not influence the reliability of the fracture assessment or the recommendation for surgical treatment [11]. Mutch et al. suggested using a greater tuberosity ratio (GT ratio) that can be applied to plain radiographs [19]. They found a very strong correlation with computed tomography (CT) scans for superior GT displacement. Furthermore, the GT ratio helped to accurately identify fractures as suitable for conservative or operative treatment or as benefitting from further imaging.
In addition, the amount of initial displacement is relevant to the decision on the treatment modality. However, there is an immediate need to reevaluate patients treated conservatively, since $50-60 \%$ of fractures show further displacement over time [22]. Younger patients are at an especially heightened risk. Hebert-Davies et al. found a 5.6-fold higher risk for secondary displacement in patients younger than 70 years compared with patients over 70 years of age [10]. Similarly, in our study, patients with secondary displacement and surgical intervention were younger than the mean age of the cohort (46 vs. 55 years).

Therefore, both aspects, the degree of displacement and how to adequately assess it, must be further investigated.

Another major finding of the present analysis is that concomitant soft tissue lesions lead to a secondary intervention after initial conservative treatment in over three quarters of the cases. In the present analysis, surgical intervention owing to secondary displacement was only performed in four cases $(3.8 \%)$. Other common interventions include capsuloligamentous and rotator cuff repairs (- Table 1). These findings highlight the need for further imaging, particularly MRI scans, to detect any concomitant lesions. Especially in patients with anterior shoulder dislocation and multifragmentary GT fracture, concomitant lesions are frequently found and require further operative treatment. Maman et al. reported on 24 arthroscopically treated patients with a GT fracture. Concomitant soft tissue lesions were found in 22 patients (94\%) [16]. These findings are supported by Katthagen et al., who found concomitant lesions (i.e., pulley/ SLAP and Bankart lesions) in $69 \%$ of patients who were treated arthroscopically for a GT fracture [14]. Again, these lesions were found more frequently after shoulder dislocations.

Muhm et al. found concomitant lesions in GT fractures with and without a dislocation [18]. However, in patients with a dislocation, concomitant lesions were more likely to be treated operatively. Interestingly, in the Muhm study, GT fractures with three or more fragments were always associated with ante- rior shoulder dislocation. In the present analysis, complex fracture patterns were found even in patients without previous shoulder dislocation, although patients were more likely to have a multi-fragmentary fracture when they sustained a shoulder dislocation. The risk for secondary surgical interventions increased with dislocations but not with multi-fragmentary fracture patterns.

\section{Limitations}

Some inherent limitations apply to the present analysis. Only patient records were analyzed, and the final functional and radiographic outcomes remain unclear in most cases. Therefore, we cannot provide proof of whether or not conservative treatment leads to good results in patients without secondary interventions. Furthermore, the decision to apply conservative treatment was not based on a distinct algorithm. There is a clear trend, however, toward conservative treatment in patients with only minimally displaced fractures. In most cases, patients with severely displaced fractures were treated conservatively when there were contraindications for surgery or when patients refused to undergo surgical treatment.

Finally, imaging modalities were not consistent in all the cases since not every patient received a CT and/or MRI scan before the decision to apply conservative treatment was made.

\section{Practical conclusion}

- With the exception of two cases, all patients included in this study had no displacement or only slight displacement of the GT fragment $(0-3 \mathrm{~mm})$ and a low risk for secondary surgical interventions.

- Secondary interventions are required more frequently after shoulder dislocation. In addition, revision surgery is most likely required because of concomitant soft tissue lesions rather than prompted by secondary displacements.

- Detailed physical examination and MRI scans should be utilized in order to screen for concomitant soft tissue 


\section{injuries accompanying GT fractures so as to prevent revision surgeries. \\ - The study highlights the need for further prospective studies in order to define clear indications for conser- vative treatment based on fracture patterns, imaging modalities, con- comitant lesions, and the patients' individual requests.}

\section{Corresponding address

PD Dr. med. B. Schliemann
Department of Trauma, Hand
and Reconstructive Surgery,
University Hospital Münster
Albert-Schweitzer-Campus,
building W1, 48149 Münster,
Germany
benedikt.schliemann@
ukmuenster.de

\section{Compliance with ethical guidelines}

Conflict of interest. B. Schliemann, L.F. Heilmann, M.J. Raschke, H. Lill, J. C. Katthagen, and A. Ellwein declare that they have no competing interests.

This article does not contain any studies with human participants or animals performed by any of the authors.

Open Access This article is distributed under the terms of the Creative Commons Attribution 4.0 International License (http://creativecommons.org/licenses/by/ 4.0/), which permits unrestricted use, distribution, and reproduction in any medium, provided you give appropriate credit to the original author(s) and the source, provide a link to the Creative Commons license, and indicate if changes were made.

\section{References}

1. Bhatia DN, De Beer JF, Van Rooyen KS (2007) The bony partial articular surface tendon avulsion lesion: an arthroscopic technique for fixation of the partially avulsed greater tuberosity fracture. Arthroscopy 23:786.e1-786.e6

2. Bono CM, Renard R, Levine RG et al (2001) Effect of displacement of fractures of the greater tuberosity on the mechanics of the shoulder. JBone Joint Surg Br 83:1056-1062

3. Chen YF, Zhang W, Chen Q et al (2013) AO $\mathrm{X}$-shaped midfoot locking plate to treat displaced isolated greater tuberosity fractures. Orthopedics 36:e995-999

4. Court-Brown CM, Garg A, Mcqueen MM (2001) The translated two-part fracture of the proximal humerus. Epidemiology and outcome in the older patient. J Bone Joint Surg Br 83:799-804

5. Dimakopoulos P, Panagopoulos A, Kasimatis Get al (2007) Anterior traumatic shoulder dislocation associated with displaced greater tuberosity fracture: the necessity of operative treatment. JOrthop Trauma 21:104-112

6. Flatow EL, Cuomo F, Maday MG et al (1991) Open reduction and internal fixation of two-part displaced fractures of the greater tuberosity of the proximal part of the humerus. J Bone Joint Surg Am 73:1213-1218

7. Gallo RA, Sciulli R, Daffner RH et al (2007) Defining the relationship between rotator cuff injury and proximal humerus fractures. Clin Orthop Relat Res 458:70-77

8. George MS (2007) Fractures of the greater tuberosity of the humerus. J Am Acad Orthop Surg 15:607-613

9. Green A, Izzi J Jr. (2003) Isolated fractures of the greater tuberosity of the proximal humerus. JShoulderElbow Surg 12:641-649

10. Hebert-Davies J, Mutch J, Rouleau D et al (2015) Delayed migration of greater tuberosity fractures associated with anterior shoulder dislocation. JOrthop Trauma 29:e396-400

11. Janssen SJ, Hermanussen HH, Guitton TG et al (2016) Greater tuberosity fractures: does fracture assessment and treatment recommendation vary based on imaging modality? Clin Orthop Relat Res 474:1257-1265

12. Jellad A, Bouaziz MA, Boudokhane $S$ et al (2012) Isolated greater tuberosity fracture: shortterm functional outcome following a specific rehabilitation program. Ann Phys Rehabil Med 55:16-24

13. Ji JH, Shafi M, Song IS et al (2010) Arthroscopic fixation technique for comminuted, displaced greater tuberosity fracture. Arthroscopy 26:600-609

14. Katthagen JC, Jensen G, Voigt $C$ et al (2014) Arthroscopy for proximal humeral fracture. Arthroskopie 27:265-274

15. Lind T, Kroner K, Jensen J (1989) The epidemiology of fractures of the proximal humerus. Arch Orthop Trauma Surg 108:285-287

16. Maman E, Dolkart O, Chechik O et al (2014) Arthroscopic findings of coexisting lesions with greater tuberosity fractures. Orthopedics 37:e272-e277

17. MattyasovszkySG, BurkhartKJ, Ahlers Cetal(2011) Isolated fractures of the greater tuberosity of the proximal humerus: a long-term retrospective study of 30 patients. Acta Orthop 82:714-720

18. Muhm M, Arend S, Winkler H et al (2017) Associated injuries with greater tuberosity fractures: mechanism of injury, diagnostics, treatment. Unfallchirurg 120:854-864

19. Mutch JA, Rouleau DM, Laflamme GY et al (2014) Accurate measurement of greater tuberosity displacement without computed tomography: validation of a method on plain radiography to guide surgical treatment. J Orthop Trauma 28:445-451

20. Neer CS 2nd (1970) Displaced proximal humeral fractures. I. Classification and evaluation. J Bone Joint Surg Am 52:1077-1089

21. Parsons BO, Klepps SJ, Miller S et al (2005) Reliability and reproducibility of radiographs of greater tuberosity displacement. A cadaveric study. J Bone Joint Surg Am 87:58-65

22. Platzer P, Kutscha-Lissberg F, Lehr S et al (2005) The influence of displacement on shoulder function in patients with minimally displaced fractures of the greater tuberosity. Injury 36:1185-1189

23. Platzer P, Thalhammer G, Oberleitner G et al (2008) Displaced fractures of the greater tuberosity: a comparison of operative and nonoperative treatment. J Trauma 65:843-848
24. Rath E, Alkrinawi N, Levy $O$ et al (2013) Minimally displaced fractures of the greater tuberosity: outcome of non-operative treatment. J Shoulder Elbow Surg 22:e8-e11

25. Robinson CM, Shur N, Sharpe T et al (2012) Injuries associated with traumatic anterior glenohumeral dislocations. J Bone Joint Surg Am 94:18-26

26. Schoffl V, Popp D, Strecker W (2011) A simple and effective implant for displaced fractures of the greater tuberosity: the "Bamberg" plate. Arch Orthop Trauma Surg 131:509-512

27. Verdano MA, Aliani D, Pellegrini A et al (2014) Isolated fractures of the greater tuberosity in proximal humerus: does the direction of displacement influence functional outcome? An analysis of displacement in greater tuberosity fractures. Acta Biomed 84:219-228 